\title{
The role of the glucocorticoids in developing resilience to stress and addiction
}

\author{
Subhashini Srinivasan ${ }^{1}$, Masroor Shariff ${ }^{2}$ and Selena E. Bartlett ${ }^{2 *}$ \\ 'Ernest Gallo Clinic and Research Center at the University of California San Francisco, Emeryville, CA, USA \\ ${ }^{2}$ Translational Research Institute and Institute for Health and Biomedical Innovation, Queensland University of Technology, Brisbane, QLD, Australia
}

\section{Edited by:}

Remi Martin-Fardon, The Scripps Research Institute, USA

\section{Reviewed by:}

Andrew Lawrence, Florey

Neuroscience Institutes, Australia

Leandro Vendruscolo, The Scripps

Research Institute, USA

*Correspondence:

Selena E. Bartlett, Faculty of Health, School of Clinical Sciences,

Translational Research Institute and Institute for Health and Biomedical Innovation, Queensland University of Technology, Brisbane, QLD 4102, Australia

e-mail:selena.bartlett@qut.edu.au
There is emerging evidence that individuals have the capacity to learn to be resilient by developing protective mechanisms that prevent them from the maladaptive effects of stress that can contribute to addiction. The emerging field of the neuroscience of resilience is beginning to uncover the circuits and molecules that protect against stress-related neuropsychiatric diseases, such as addiction. Glucocorticoids (GCs) are important regulators of basal and stress-related homeostasis in all higher organisms and influence a wide array of genes in almost every organ and tissue. GCs, therefore, are ideally situated to either promote or prevent adaptation to stress. In this review, we will focus on the role of GCs in the hypothalamic-pituitary adrenocortical axis and extra-hypothalamic regions in regulating basal and chronic stress responses. GCs interact with a large number of neurotransmitter and neuropeptide systems that are associated with the development of addiction. Additionally, the review will focus on the orexinergic and cholinergic pathways and highlight their role in stress and addiction. GCs play a key role in promoting the development of resilience or susceptibility and represent important pharmacotherapeutic targets that can reduce the impact of a maladapted stress system for the treatment of stress-induced addiction.

Keywords: addiction, glucocorticoid, stress, resilience, cholinergic, nicotinic acetylcholine receptors, mifepristone, orexin

\section{INTRODUCTION}

Susceptibility to developing an addiction is governed by genetics and modified by experience and the environment. Stress plays an important role in increasing susceptibility to addiction. McEwen eloquently wrote that, "human lifetime experiences have a profound impact on the brain, both as a target of stress and allostatic load/overload and as a determinant of physiological and behavioral response to stressors" (1). The ability to cope with stress or resilience (the capacity to bounce back following adversity) significantly predicts whether a person will subsequently develop a stress-related neuropsychiatric disease such as anxiety, depression, and addiction [reviewed in (2)]. A large majority of population have experienced a traumatic event during their lifetime. However, only a small percentage will subsequently experience chronic distress leading to post-traumatic stress disorder (PTSD) or addiction to alcohol or other drugs (3). In most cases, however, people have resilience and do not develop a disease or disorder following exposure to stressors. The emerging field of the neuroscience of resilience is uncovering new circuits and molecules that serve to protect against stress-related neuropsychiatric diseases.

It has often been assumed that resilience is an innate or passive mechanism that cannot be changed. However, research in animals and humans suggest that developing resilience may be a learnt behavior (2). Individuals have the capacity to learn to be resilient by developing mechanisms that protect from the maladaptive effects of stress. Glucocorticoids (GCs), cortisol in humans, or corticosterone in rodents are important regulators of basal and stress-related homeostasis and have been shown to modulate an array of genes in many organs and tissues (4-6). Thus, GCs are ideally placed to regulate a multitude of signaling pathways activated in response to stress and addiction. In this review, we will focus on the role of GCs in the hypothalamicpituitary adrenocortical (HPA) axis in regulating basal and chronic stress responses. In addition, we will focus on two systems, the orexinergic and cholinergic systems and their roles in mediating stress and addiction. We will further discuss the emerging interaction between these systems with GCs and in regulation of stress. Lastly, as GCs play a key role in promoting either resilience or susceptibility to stress, we will examine the pharmacotherapeutic opportunities that target GCs for the treatment of stress-induced addiction.

\section{THE ROLE OF THE HPA AXIS AND THE GLUCOCORTICOIDS IN THE NEUROBIOLOGY OF RESILIENCE TO STRESS}

The mechanisms that govern an organism's ability to handle stress has been well described in microorganisms that have specialized hubs, called stressosomes, that govern responses to an array of physical and environmental insults $(7,8)$. The stressosome is a unique structure within the microorganism that precisely orchestrates the molecular machinery that tunes the magnitude of the response to a stressor. The stressosome ultimately ensures the survival of the cell in response to an extensive variety of chemical and physical stressors $(7,8)$. The mammalian correlate of the "stressosome" is the HPA axis, as it provides a co-ordinated response to acute stress (9). The fundamental components of the central HPA 
axis are well known and include the corticotropin-releasing hormone $(\mathrm{CRH})$-secreting neurons of the paraventricular nucleus of the hypothalamus (PVN) (10) that stimulate pituitary adrenocorticotropic hormone (ACTH) and adrenal corticosterone (CORT) secretion (11).

Glucocorticoids are steroid hormones that are secreted by the adrenal glands and are important regulators of homeostasis in basal and stressful conditions. GCs exert their influence through two types of intracellular receptors the type I mineralocorticoid receptor and type II glucocorticoid receptor. Both receptors are expressed throughout the body and exert systemwide effects. In the brain, the high affinity type I mineralocorticoid receptor (also called aldosterone receptor in the kidneys), is expressed predominantly in the hippocampal formation and moderate expression is found in prefrontal cortex (PFC) and amygdala (12-14). The low affinity type II GRs are expressed throughout the brain with highest expression in the PVN and hippocampus and because of its lower affinity to cortisol it plays a key role in stress-related homeostasis when circulating levels of cortisol are high (14-17). GRs and MRs receptors reside in the cytoplasm and mediate classical genomic actions of GCs by acting as nuclear transcriptional activators and repressors $(14,18)$ and membrane bound GRs mediate the rapid actions of GCs $(19,20)$. GCs are thus ideally positioned to modulate responses to stress and be activated in the brain during healthy conditions, following acute stress and during adaptation of responses to chronic stress $(4,5,21)$.

Glucocorticoids provide inhibitory feedback responses over fast (seconds to minutes) and longer (hours to days) timescales $(4,18,22-24)$. The rapid effects involve immediate reduction in miniature EPSC frequency upon application of corticosterone or dexamethasone (synthetic GC) in the PVN (25), and reduced $\mathrm{ACTH}$ and corticosterone levels, an effect not observed when membrane impermeable dexamethasone was used, indicating fast feedback inhibition (26). Similar rapid effects of corticosterone on mEPSC in the hippocampus have been observed $(27,28)$. Thus both short time scale (perhaps non-genomic) and longer time scale (genomic) actions of GC together mediate the inhibitory feedback control. The molecular and neurobiological processes that underpin passive and active resilience are being investigated and candidates are regulators of the HPA axis, molecules involved in the architecture of the synapse and signaling molecules associated with neural plasticity [reviewed by (2)]. GCs represent the end product of the HPA axis and influence many functions of the central nervous system, such as arousal, cognition, mood, sleep, metabolism, and cardiovascular tone, immune, and inflammatory reaction (Figure 1).

Repeated traumatic events induce long-lasting behavioral changes that affect cognitive, emotional, and social behaviors that ultimately provide an organism protection or survival. The ability to handle stress may depend on an individual's HPA axis responsiveness that may in turn predict the likelihood of developing neuropsychiatric disorders such as addiction. However, under chronic stress this feedback becomes dysregulated leading to the variety of maladaptive syndromes, such as anxiety and various forms of depressive disorders $(1,5,29-33)$ and addiction, including alcohol dependence (34). It has been shown that dysregulation

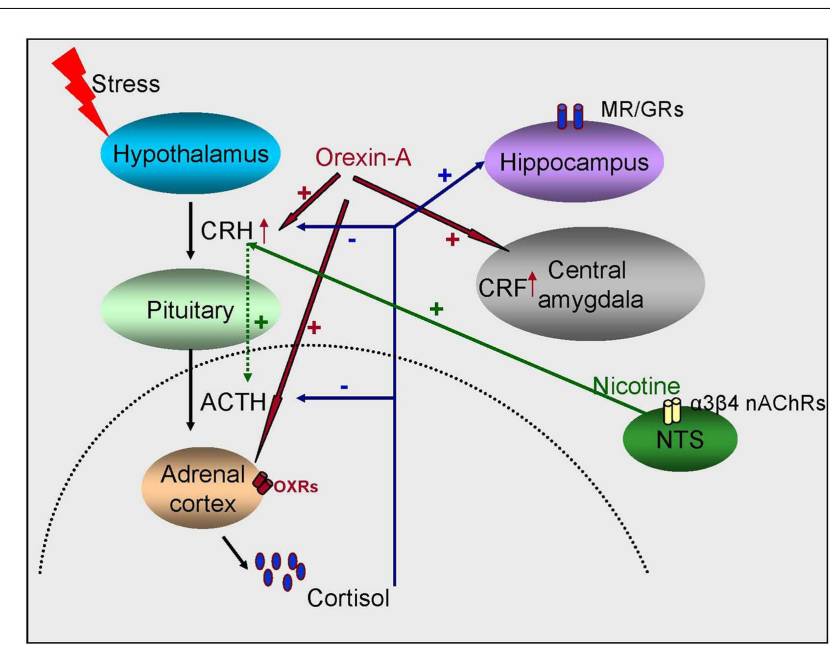

FIGURE 1 | Schematic representation of the interaction between glucocorticoids, orexins, and the cholinergic system in regulating stress responses. Stress activates the release of glucocorticoids from the adrenal gland, which then feedback into the brain and target both the HPA axis and extra-hypothalamic sites like the hippocampus and the amygdala. Orexins also activate the HPA axis and lead to the production of glucocorticoids and stimulate the release of CRF from the PVN of the hypothalamus and the central amygdala. The third player are the nicotinic receptors ( $\mathrm{ACChRs}$ ) which indirectly regulate $\mathrm{ACTH}$ release by acting on the PVN.

of the HPA axis by chronic and uncontrollable stress leads to abnormal GC secretion $(35,36)$. GRs mediate adaptation to stress and regulate termination of the stress response through negative feedback at the level of the HPA axis (30-32). GCs can dynamically regulate tissue sensitivity in a stochastic manner (5) and control the response to chronic stress. GCs regulate tissue and organ sensitivity by modulating GRs signaling, ligand availability, receptor isoform expression, intracellular circulation, and promoter association (30-32).

\section{GLUCOCORTICOID RECEPTORS IN MALADAPTIVE STRESS RESPONSES: THE ROLE OF CHANGES IN PLASTICITY IN THE AMYGDALA}

The amygdala is a key brain region that is involved in processing stress, fear, and pavlovian conditioning, and is a site where neuroendocrine signals stimulated by fear and stress interact. It has been proposed that the balance between hippocampal and amygdalar learning is important for determining behavioral stress coping choices. Chronic restraint stress increases dendritic growth and spine density in the basolateral amygdala (BLA) and is in contrast to its role in the hippocampus. The changes in the hippocampus return to baseline during recovery, whereas those in the amygdala are long lasting (37). Neurotrophic factors like BDNF mediate the stress-induced alternations in these brains regions. A recent study demonstrated that increased levels of BDNF are found in response to chronic stress in the BLA, whereas decreased levels were observed in the hippocampus (38). Animals which escape from aggressive interactions seem to have a more robust BDNF expression profile in the hippocampus and less in the amygdala, 
while the opposite behavior (of stay and face the opponent) have the opposite effect (39). Thus stress activates neurotrophic factors in different brain regions and is thought to be mediated by the GR system. Mice with a targeted genetic deletion of the GR, specifically in the central nucleus of the amygdala (CeA) but not in the forebrain have decreased conditioned fear responses (40). In contrast, targeted forebrain disruption of GRs, excluding the CeA, did not. It is known that the GRs in BLA are involved in consolidation of emotionally arousing and stressful experiences in rodents and humans by interacting with noradrenaline. Human studies have demonstrated that interactions between noradrenergic activity and glucocorticoid stress hormones can bring out disruptions in the neural basis of goal-directed action to habitual stimulus-response learning (41). Recently, it was shown that following acute stress, LTP induction is facilitated in the BLA by both $\beta$-adrenergic and GRs activation (42). Taken together, there are circuit specific changes underlying learning during stressful conditions, animals that are susceptible to stress have greater increases in synaptic activity in fear-related circuits such as the amygdala compared to animals that are resilient to stress.

\section{GLUCOCORTICOIDS DRIVE CHANGES IN PLASTICITY IN THE HIPPOCAMPUS AND CORTICAL REGIONS IN RESPONSE TO STRESS}

Glucocorticoid receptors in the hippocampus control homeostasis during healthy conditions and then play a role in driving changes in plasticity in response to stressful conditions $(43,44)$. Early life experiences that ultimately control an individual's HPA responsivity to stressful stimuli are modulated by GR gene expression in the hippocampus and frontal cortex (45). Hippocampal GRs play a role in the formation of long-term inhibitory avoidance memory in rats by inducing the CaMKII $\alpha$-BDNF-CREB-dependent neural plasticity pathways (46). In a separate study, chronic exposure to corticosterone resulted in impaired ability to learn response outcomes (47). Memory consolidation is thought to be mediated by the GR, while appraisal and responses to novel information is processed by the MR. Human and rodent studies suggest that under stressful conditions there is a switch from cognitive memory mediated by the hippocampus to habit memory mediated by the caudate nucleus $(48,49)$. In fact, mice deficient in MR receptors have impaired spatial memory, however they were rescued from further deterioration by stimulus-response memory following stress (50). Similarly, following an acute stressor, GRs are activated and induce synaptic plasticity in the PFC by increasing trafficking and function of NMDARs and AMPARs (51). Furthermore, when the MR was overexpressed in the forebrain of mice using a CAMkIIa promoter driven expression of HA-tagged human MR cDNA, the mice showed improved spatial memory, reduced anxiety without alteration in baseline HPA stress responses (52). There is mounting evidence that GCs participate in the formation of memories in specific circuits that govern stress responses and consequently responses to substances of abuse and alcohol.

\section{GLUCOCORTICOIDS IN THE DEVELOPMENT OF ADDICTION}

Chronic exposure to stress leads to alterations in the homeostatic functioning of GCs (29). Furthermore, there is significant dysregulation of the HPA axis following alcohol dependence. It has been shown that acute voluntary ethanol self-administration increases corticosterone levels, in contrast, long-term ethanol exposure in rodents results in a blunted response suggesting the alcohol dependence leads to dysregulation of the HPA axis (53). Transient overexpression of GR in young animals is both necessary and sufficient for bringing about profound changes in the transcriptome in specific brain regions leading to a lifelong increase in vulnerability to anxiety and drugs of abuse (54). The modified transcripts have been implicated in GR and axonal guidance signaling in dentate gyrus and dopamine receptor signaling in nucleus accumbens (NAc) (54). Furthermore, in some individuals, following exposure to stress and psychological trauma, GCs can promote escalated drug-taking behaviors and induce a compromised HPA axis. GCs can cross-sensitize with stimulant drug effects on dopamine transmission within the mesolimbic dopamine reward/reinforcement circuitry (55) and increase susceptibility to developing addictive behaviors (56-58) by increasing the synaptic strength of dopaminergic synapses (59). Importantly, the dopamine responses in the NAc core, but not the shell, have been shown to respond to fluctuating levels of GCs (60). Deficiencies in the GR gene in mice specifically in dopaminergic neurons expressing dopamine D1 receptors that receive dopaminergic input had decreased cocaine self-administration and dopamine cell firing (61). Acute exposure or binge-like ethanol exposure alter GC levels and promote PFC GC-regulated gene expression (62) and neurodegeneration that is dependent on type II GRs (63). GCs induce ethanol associated plasticity of glutamatergic synapses that have been proposed to underlie the development of ethanol dependence, reviewed in (64).

It has been shown that there is a correlation between acute alcohol withdrawal and downregulation of GR mRNA in the PFC, NAc, and bed nucleus of the stria terminalis (BNST), while protracted alcohol abstinence correlated with upregulated GR mRNA in the NAc core, ventral BNST, and CeA $(65,66)$, reviewed in (67). The transition from initial voluntary drug use to subsequent compulsive drug use has been proposed to reflect a switch from goal-directed to habitual control of action behavior (68). The investigators propose that acute stressors reinstate habitual responding to drug-related cues and repeated stress may promote the transition from voluntary to compulsory drug use. GCs are ideally positioned to regulate a diverse array of systems that modulate the development of addiction. In the following sections, we review the interplay between GCs and the orexinergic and cholinergic systems.

\section{THE OREXINERGIC SYSTEM}

The most studied biological functions of orexins/hypocretins are in the central control of feeding, sleep, energy homeostasis, and reward-seeking. Orexin-A and orexin-B (also called hypocretin-1 and -2) interact with two orexin/hypocretin receptor subtypes, the Orexin 1 Receptor (OX1R) and Orexin 2 Receptor (OX2R) which bind to either or both orexin-A and orexin-B $(69,70)$. Initial discoveries on the role of orexins came about with identification of deficiencies in the genes either encoding orexin or the OX2R receptor resulting in canine narcolepsy, implicating the role of ORX/Hcrt system in the regulation of sleep and wakefulness $(71,72)$. Orexin-A and orexin-B have been shown 
to increase food intake that is blocked by selective antagonists $(73,74)$. In addition, orexinergic fibers innervate various brain regions involved in energy homeostasis, such as the ventromedial hypothalamic nucleus, the arcuate nucleus, and the PVN of the hypothalamus (75). Orexins regulate autonomic functions, such as regulation of blood pressure and heart rate (76). Thus these neuropeptides are in a unique position to respond to stress.

\section{ROLE OF OREXINS IN STRESS AND ACTIVATION OF THE HPA AXIS}

Arousal is an important element of the stress response and the orexin system is a key component of the response to stress. Projections from perifornical nucleus and the dorsomedial nucleus of the hypothalamus are also implicated in addictive behaviors, however their role in arousal and concomitant stress has been the main focus (77). Orexins modulate the HPA axis in response to different stressful stimuli. Prepro-orexin mRNA expression was increased in the lateral hypothalamus ( $\mathrm{LH})$ in young rats following immobilization stress and in adult rats following cold stress (78). OX-A activates the HPA axis inducing secretion of ACTH and corticosterone (79). OX-A, but not OX-B, increases glucocorticoid secretion from rat and human adrenal cortices by direct stimulation of adrenocortical cells via OX1R coupled to the adenylate cyclase-dependent cascade (79) (Figure 1). Intracerebroventricular (I.C.V) administration of OX-A enhanced ACTH and corticosterone release (80-82). It has been proposed that orexin neurons play an integrative role that links autonomic responses to arousal and/or vigilance during the fight-or-flight response (83) (Figure 2).

\section{ROLE OF OREXINS IN ADDICTION}

Along with the many functions performed by orexins, the most intriguing is their role in the reward system. Orexin containing neurons project from the $\mathrm{LH}$ to the ventral tegmental area (VTA) and NAc, the brain regions that comprise the mesolimbic "reward pathway" (84-86). OXRs have recently been implicated in the motivational drive for addictive substances such as morphine, cocaine (87-91), and alcohol (92-97). The OX1R plays a specific role in ethanol self-administration, cue, and stressinduced relapse, reviewed in (98) with a more limited role for OX2R being shown (99). The orexin system has also been implicated in relapse to drug use. The OX1R plays a role in foot-shock stress-induced reinstatement of cocaine $(100,101)$ and cue and yohimbine induced reinstatement of ethanol-seeking $(94,96,102)$.

The central amygdaloid projections regulate the HPA axis and innervate orexin containing neurons in the lateral hypothalamus. The extended amygdala which includes the CeA, BNST, and the NAc are critical brain areas that process emotional behaviors such as anxiety, fear, stress, and drug addiction. In particular, the CeA and BNST have been shown to play an important role in anxietyrelated behaviors and voluntary ethanol consumption (103). The extended amygdala, including the $\mathrm{CeA}$, has been shown to play a critical role in the reinstatement behavior to drugs of abuse. Inactivation of the CeA, but not the BLA, prevents foot-shock-induced reinstatement of cocaine-seeking (104). Dense orexinergic innervation is also observed in all these brain regions $(76,105,106)$. These brain regions also express stress peptides such as corticotrophin releasing factor (CRF) and anti-stress peptides such as neuropeptide Y (NPY). Both these neuropeptides have opposing actions in the $\mathrm{CeA}$ and regulate ethanol consumption. OX-A

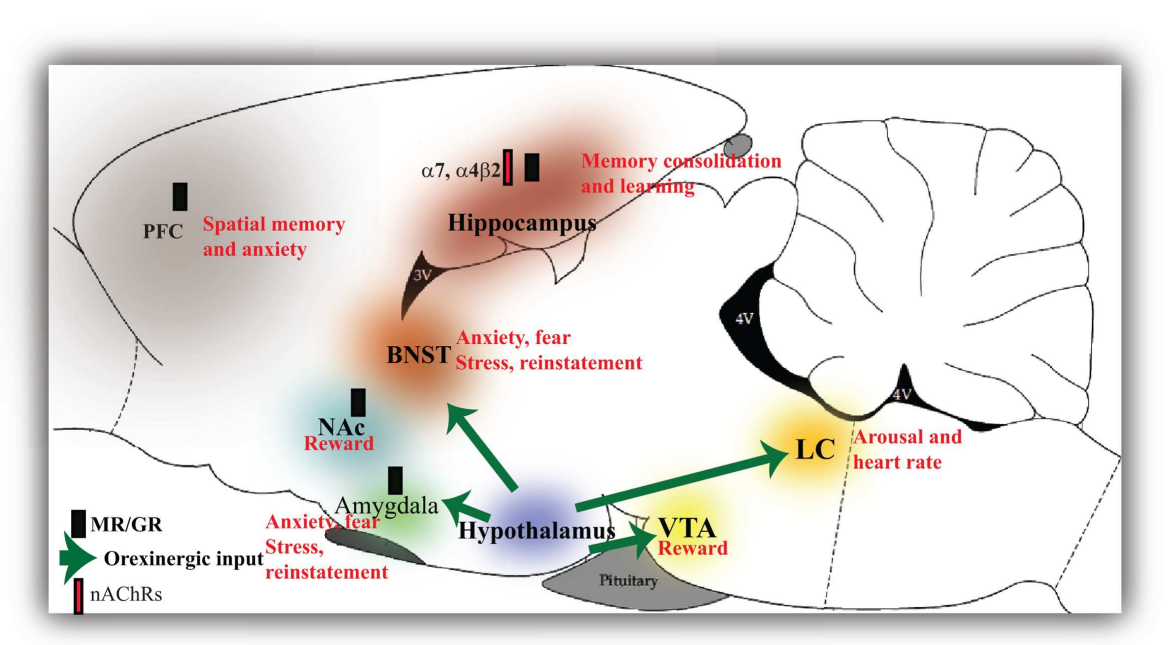

FIGURE 2 | Glucocorticoid, orexinergic, and cholinergic activation of the brain regions involved in stress and drug addiction. Glucocorticoid receptors in the hippocampus and amygdala mediate the effects of stress and consolidation of fearful memories. GCs also modulate alcohol withdrawal in the prefrontal cortex (PFC), nucleus accumbens (NAc), and bed nucleus of the stria terminalis (BNST). Glucocorticoids (GCS) in the hippocampus also negatively regulate the hypothalamus thereby providing a central feedback mechanism. Orexins produced in the hypothalamus activate reward pathways such as the ventral tegmental area (VTA) and the $\mathrm{NAc}$ and brain regions involved in stress, fear, and anxiety such as the amygdala and BNST and regulate cardiovascular tone through the locus coeruleus (LC). Both GCs and orexins play similar roles in brain regions implicated in stress and reward. Glucocorticoids have been shown to directly inhibit nicotinic receptor (nAChR) activity in the hippocampus that exert an inhibitory effect on the HPA axis. The nAChRs seem to differentially orchestrate responses to stress. 
infusions into the BNST produce anxiety like responses as measured by social interaction test and elevated plus maze test and the effect is mediated by NMDA receptors (107). A recent study also demonstrated that yohimbine activates orexinergic responses, but not adrenergic receptor activity, and depressed excitatory neurotransmission in the BNST that contributed to reinstatement of extinguished cocaine CPP (108). Thus the orexinergic system is involved in mediating stress-induced drug-seeking behavior as it recruits multiple brain regions involved in processing stressful stimuli and addictive behaviors. It is essential to understand the contribution of orexins in the overlap between stress and reward systems. Identifying circuits that mediate stress-induced relapse to drug abuse will be necessary in order to develop targeted pharmacotherapeutic approaches for stress-induced drug relapse. The dual orexin receptor antagonist, suvorexant (109) has successfully completed phase III clinical trials in treating primary insomnia and is currently under FDA review. If approved, this will be the first FDA orexin antagonist available for treating sleep-disorders and has the potential to be repurposed for its efficacy in treating stress and addictive disorders.

\section{INTERACTIONS BETWEEN THE CHOLINERGIC SYSTEM AND HPA AXIS}

Allostasis, a process by which homeostasis is regained after stress, occurs by the interaction between the PFC, amygdala, and the hippocampus via the HPA axis (110-113). In this process a number of neurotransmitters and neuromodulators such as acetylcholine, glutamate, and GABA, have been shown to be differentially modulated. Here, we review the involvement of the components of the cholinergic pathway in reacting to, sustaining, and even exacerbating stress.

Components of the cholinergic pathway are - the ligand, acetylcholine (ACh); the enzyme responsible for the breakdown of acetylcholine, acetylcholinesterase (AChE); the enzyme involved in synthesizing ACh, choline acetyltransferase (ChAT); and, the acetylcholine receptors, nicotinic acetylcholine receptor (nAChR), and muscarinic acetylcholine receptor (mAChR). We are focusing specifically on the nicotinic receptor $-\mathrm{nAChR}-$ in relation to the cholinergic response to stress. By focusing on the $n A C h R$ cholinergic pathway, it is not our purpose to suggest that $\mathrm{nAChR}$ is the only or a more important player mediating responses to stress. Rather, it is intended that this review highlights the interactions of the glucocorticoid pathway (mediated via the HPA) and the nAChR-cholinergic pathway in relation to stress.

It is well known that the nAChRs are involved in learning and memory $(114,115)$. Additionally, the negative effects of chronic stress on memory are also well established $(116,117)$. Indeed, as early as 1968, the hippocampus was recognized as a target structure for stress hormones (118) with observations that acetylcholine release into the hippocampus $(119,120)$ increased under various stress models (121). Transgenic mouse knock-out models have shown the importance of the $\alpha 4$ (122), $\beta 3$ (123), and $\beta 4$ (124) nAChR subunits in mediating the anxiogenic effects of stress. Furthermore, the $\alpha 5$ and $\beta 4$ knock-out mice are less sensitive to nicotine $(125,126)$, a potent anxiolytic agent $(127-$ 129) at lower doses (130). Indeed, the $\alpha 7$ and $\alpha 4 \beta 2$ nAChRs, which are the primary targets of nicotine, have been shown to provide a nicotine-mediated neuroprotective effect in stressinduced impairment of hippocampus-dependent memory (131). The hippocampus has been shown to exert an inhibitory effect on the HPA axis (132-136), thus lowering stress. Taken together, the $\mathrm{nAChR}$ seem to differentially orchestrate responses to stress via its various subunits.

Activation of the stress response is due to the cascading efflux of $\mathrm{CRH}, \mathrm{ACTH}$, and cortisol. Nicotine, a potent ligand at nAChRs, in relatively high doses $(2.5-5.0 \mu \mathrm{g} / \mathrm{kg})$ has been shown to produce a dose-dependent increase in ACTH (137), and its antagonist, mecamylamine, has been shown to block nicotine-stimulated ACTH release $(137,138)$. In the brain, the region responsible for the CRH-mediated ACTH release is the parvocellular region of the PVN (pcPVN) of the hypothalamus $(139,140)$. It has, however, been shown that nicotine mediates ACTH release indirectly, via the nicotinic receptors on the nucleus tractus solitarius (NTS) $(141,142)$. The NTS subsequently mediates action potentials via various afferents to the pcPVN $(143,144)$. The nAChR in the NTS are found pre-synaptically on glutamatergic projections to the pcPVN $(145,146)$. Further, the nAChR subunits implicated in the nicotine-mediated effects of ACTH in this pathway are the $\beta_{4}$-containing nAChRs (most likely $\alpha_{3} \beta_{4}{ }^{*}$ ) but not the $\alpha_{4} \beta_{2}$ as determined by measurements of mEPSCs in the presence of $\mathrm{DH} \beta \mathrm{E}$, a potent $\alpha_{4} \beta_{2}$ inhibitor or cytisine, a potent $\beta_{4}{ }^{*}$-nAChR agonist (146). Therefore, while the $\alpha_{4} \beta_{2}$ and $\alpha_{7} \mathrm{nAChR}$ subunits modulate nicotine-mediated roles elsewhere (131), in the NTS it is a different subtype (146), pointing yet again to a nAChR-based differential modulation to stress (Figure 1).

\section{GLUCOCORTICOID INTERACTIONS WITH THE CHOLINERGIC SYSTEM}

Glucocorticoids have been shown to directly inhibit nAChR activity (147-149). This is supported by the fact that stress causes a down regulation of the $\mathrm{nAChR}$ in the rat cerebral cortex and midbrain (150). Additionally, steroid antagonists have been shown to upregulate nAChR expression (151). That GCs can directly affect $\mathrm{nAChR}$ activity via receptor binding or alteration of expression levels can be explained by the presence of glucocorticoid response elements (GRE) on genes transcribing the $\alpha_{7}$ subunit of the nAChR - CHRNA7 (152). Indeed, GREs have also been identified on genes for ChAT (153) and AChE (154), components of the cholinergic pathway. Further research is required to study the precise effects of these GREs in this pathway along with investigating if these GRE are also present on other nAChR genes.

Other components of the cholinergic pathway too have been shown to be affected by stress. AChE, responsible for the timely degradation of $\mathrm{ACh}$, has been shown to be regulated via alternative splicing thus modifying neurotransmission (155). Indeed, miRNA post-transcriptional modification of AChE from its usual AChE-S to the read-through form AChE-R alters cholinergic transmission (156). Additionally, post-transcriptional modulation of AChE, again via miRNA, causes hippocampal-related cognitive defects (157). As stated earlier, AChE expression is controlled at the genomic level via the GRE (154) as is ChAT (153). Also, ChAT protein levels were shown to decrease due to chronic stress (158). At the epigenetic level, there is stress-induced epigenetic transcriptional memory of AChE via HDAC4 (159). Interestingly, in 
this study a GRE was also identified on HDAC4 (159), suggesting a direct epigenetic effect of stress on AChE. All these results point to a multi-faceted mechanism whereby the stress-induced cholinergic response is regulated without the over-articulation of its response that would undoubtedly lead to various stressrelated neuropathologies such as PTSD $(160,161)$, alcohol addiction $(162,163)$, and addiction to other substances of abuse $(164,165)$.

In summary, the involvement of the different subtypes of the $\mathrm{nAChR}$ in different regions of the brain along with modulation of the cholinergic pathway at various stages such as transcriptional, post-transcriptional, and epigenetic modifications, point to a finely modulated system both temporally and spatially that is attuned to respond to the various stressors that we are faced with in our daily lives. Lastly, while this review has focused on the nAChR and the cholinergic pathway, the involvement of the muscarinic receptor and a myriad other neural circuits cannot be understated. Indeed the ultimate goal of this field of research is to understand sufficiently the intricate interplay between the various pathways and neural circuits that ultimately will enable the alleviation of stress-induced morbidity via development of more effective pharmacotherapeutic strategies against stress.

\section{PHARMACOTHERAPEUTIC STRATEGIES}

Ample evidence exists to demonstrate that type II GRs are important therapeutic targets for the treatment of disorders that result from maladaptive stress responses. Mifepristone, also known as RU486, is a derivative of the 19-norprogestin norethindrone and potently competes with type II GRs and progesterone receptors (PRs). Mifepristone has been shown to reduce reinstatement of ethanol-seeking and escalated drinking in two different animal models $(66,166)$. Furthermore, mifepristone has been shown to be effective at reducing the self-administration of amphetamine

\section{REFERENCES}

1. McEwen BS. Protection and damage from acute and chronic stress: allostasis and allostatic overload and relevance to the pathophysiology of psychiatric disorders. Ann $N$ $Y$ Acad Sci (2004) 1032:1-7. doi:10.1196/annals.1314.001

2. Russo SJ, Murrough JW, Han MH, Charney DS, Nestler EJ. Neurobiology of resilience. Nat Neurosci (2012) 15:1475-84. doi:10.1038/nn. 3234

3. Nechvatal JM, Lyons DM. Coping changes the brain. Front Behav Neurosci (2013) 7:13. doi:10.3389/fnbeh.2013. 00013

4. De Kloet ER, Vreugdenhil E, Oitzl MS, Joels M. Brain corticosteroid receptor balance in health and disease. Endocr Rev (1998) 19:269-301. doi:10.1210/er.19.3.269
5. Kino T. Tissue glucocorticoid sensitivity: beyond stochastic regulation on the diverse actions of glucocorticoids. Horm Metab Res (2007) 39:420-4. doi:10.1055/s-2007-980193

6. McEwen BS, De Kloet ER, Rostene W. Adrenal steroid receptors and actions in the nervous system. Physiol Rev (1986) 66: 1121-88.

7. Liebal UW, Millat T, MarlesWright J, Lewis RJ, Wolkenhauer O. Simulations of stressosome activation emphasize allosteric interactions between RsbR and RsbT. BMC Syst Biol (2013) 7:3. doi:10.1186/1752-0509-7-3

8. Marles-Wright J, Grant T, Delumeau $\mathrm{O}$, van Duinen G, Firbank SJ, Lewis PJ, et al. Molecular architecture of the "stressosome," a signal integration and transduction hub. Science (2008) 322:92-6. doi:10.1126/science. 1159572

(167), cocaine $(168,169)$, morphine (170), and ethanol $(57,66$, $162,166,171-175)$. A recent study also demonstrates the effectiveness of mifepristone in reducing withdrawal symptoms of alcohol (176). The anti-glucocorticoid activity of mifepristone has made it a potential treatment for Cushing's syndrome (177) and neurological and psychological disorders (178-183). Mifepristone offers a promising way to temporarily reset the stress response system that has become maladapted following chronic and long-term alcohol consumption.

\section{CONCLUSION}

Learning to cope with life and/or stress or learning to be susceptible to stress involves dynamic regulation of plasticity in brain circuits that govern stress response pathways. As the brain can be remodeled by experience and neural circuits are adaptable and dynamically regulated, this suggests it is possible to change the brain or learn how to cope with stress and overcome addiction and learn to become more resilient. The molecular pathways and circuits that govern resilience are gradually being uncovered and this will provide opportunities for identifying novel strategies that overcome the impact of addiction on the brain combined with possible novel pharmacotherapeutic strategies that target pro-resilience pathways. In this review, we focused on the role of glucocorticoid hormones, as they have the capacity to provide system-wide feedback during acute and chronic stress and provide a way forward to interrogate and reset brain networks. Understanding the molecular mechanisms that govern mechanisms that the brain utilizes to protect from the deleterious effects of stress will provide exciting new avenues in neuroscience.

\section{ACKNOWLEDGMENTS}

This work was supported by funding from the ARC Future Fellowship (Selena E. Bartlett).

9. Selye $H$. The significance of the adrenals for adaptation. Science (1937) 85:247-8. doi:10.1126/science.85.2201.247

10. Herman JP, Figueiredo $\mathrm{H}$ Mueller NK, Ulrich-Lai Y, Ostrander MM, Choi DC, et al. Central mechanisms of stress integration: hierarchical circuitry controlling hypothalamopituitary-adrenocortical responsiveness. Front $\mathrm{Neu}$ roendocrinol (2003) 24:151-80. doi:10.1016/j.yfrne.2003.07.001

11. Ulrich-Lai YM, Herman JP. Neural regulation of endocrine and autonomic stress responses. Nat Rev Neurosci (2009) 10:397409. doi:10.1038/nrn2647

12. Arriza JL, Simerly RB, Swanson LW, Evans RM. The neuronal mineralocorticoid receptor as a mediator of glucocorticoid response. Neuron (1988) 1:887-900. doi:10.1016/08966273(88)90136-5
13. Arriza JL, Weinberger C, Cerelli G, Glaser TM, Handelin BL, Housman DE, et al. Cloning of human mineralocorticoid receptor complementary DNA: structural and functional kinship with the glucocorticoid receptor. Science (1987) 237:268-75. doi:10.1126/science 3037703

14. Reul JM, de Kloet ER. Two receptor systems for corticosterone in rat brain: microdistribution and differential occupation. Endocrinology (1985) 117:2505-11. doi:10.1210/endo117-6-2505

15. Aronsson M, Fuxe K, Dong Y, Agnati LF, Okret S, Gustafsson JA. Localization of glucocorticoid receptor mRNA in the male rat brain by in situ hybridization. Proc Natl Acad Sci U S A (1988) 85:93315. doi:10.1073/pnas.85.23. 9331 
16. Gustafsson JA, Carlstedt-Duke J, Poellinger L, Okret S, Wikstrom AC, Bronnegard M, et al. Biochemistry, molecular biology, and physiology of the glucocorticoid receptor. Endocr Rev (1987) 8:185-234. doi:10.1210/edrv-82-185

17. Spencer RL, Young EA, Choo $\mathrm{PH}, \mathrm{McEwen}$ BS. Adrenal steroid type I and type II receptor binding: estimates of in vivo receptor number, occupancy, and activation with varying level of steroid. Brain Res (1990) 514:37-48. doi:10.1016/00068993(90)90433-C

18. Groeneweg FL, Karst H, de Kloet ER, Joels M. Rapid non-genomic effects of corticosteroids and their role in the central stress response. J Endocrinol (2011) 209:153-67. doi:10.1530/JOE-10-0472

19. de Kloet ER, Karst H, Joels M. Corticosteroid hormones in the central stress response: quick-and-slow. Front $\mathrm{Neu}$ roendocrinol (2008) 29:268-72. doi:10.1016/j.yfrne.2007.10.002

20. Hinz B, Hirschelmann R. Rapid non-genomic feedback effects of glucocorticoids on CRFinduced ACTH secretion in rats. Pharm Res (2000) 17:1273-7. doi:10.1023/A:1007652908104

21. Sapolsky RM, Romero LM, Munck AU. How do glucocorticoids influence stress responses? Integrating permissive, suppressive, stimulatory, and preparative actions. Endocr Rev (2000) 21:55-89. doi:10.1210/er.21.1.55

22. Grino $M$, Burgunder JM, Eskay RL, Eiden LE. Onset of glucocorticoid responsiveness of anterior pituitary corticotrophs during development is scheduled by corticotropinreleasing factor. Endocrinology (1989) 124:2686-92. doi:10.1210/endo-124-6-2686

23. Keller-Wood ME, Dallman MF. Corticosteroid inhibition of ACTH secretion. Endocr Rev (1984) 5:1-24. doi:10.1210/edrv-5-1-1

24. Tasker JG, Di S, MalcherLopes R. Minireview: rapid glucocorticoid signaling via membrane-associated receptors. Endocrinology (2006) 147:5549-56. doi:10.1210/en. 2006-0981

25. Di S, Malcher-Lopes R, Halmos KC, Tasker JG. Nongenomic glucocorticoid inhibition via endocannabinoid release in the hypothalamus: a fast feedback mechanism. J Neurosci (2003) 23:4850-7.

26. Evanson NK, Tasker JG, Hill MN, Hillard CJ, Herman JP. Fast feedback inhibition of the HPA axis by glucocorticoids is mediated by endocannabinoid signaling. Endocrinology (2010) 151:48119. doi:10.1210/en.2010-0285

27. Karst $H$, Berger S, Turiault $M$, Tronche F, Schutz G, Joels M. Mineralocorticoid receptors are indispensable for nongenomic modulation of hippocampal glutamate transmission by corticosterone. Proc Natl Acad Sci U S A (2005) 102:19204-7. doi:10.1073/pnas.0507572102

28. Qiu S, Champagne DL, Peters M, Catania EH, Weeber EJ, Levitt P, et al. Loss of limbic system-associated membrane protein leads to reduced hippocampal mineralocorticoid receptor expression, impaired synaptic plasticity, and spatial memory deficit. Biol Psychiatry (2010) 68:197-204. doi:10. 1016/j.biopsych.2010.02.013

29. Barik J, Marti F, Morel C, Fernandez SP, Lanteri C, Godeheu $\mathrm{G}$, et al. Chronic stress triggers social aversion via glucocorticoid receptor in dopaminoceptive neurons. Science (2013) 339:332-5. doi:10.1126/science. 1226767

30. De Kloet ER, Reul JM. Feedback action and tonic influence of corticosteroids on brain function: a concept arising from the heterogeneity of brain receptor systems. Psychoneuroendocrinology (1987) 12:83-105. doi:10.1016/03064530(87)90040-0

31. Diorio D, Viau V, Meaney MJ. The role of the medial prefrontal cortex (cingulate gyrus) in the regulation of hypothalamicpituitary-adrenal responses to stress. J Neurosci (1993) 13:3839-47.

32. Magarinos AM, Somoza G, De Nicola AF. Glucocorticoid negative feedback and glucocorticoid receptors after hippocampectomy in rats. Horm Metab Res (1987) 19:105-9. doi:10.1055/s2007-1011753

33. McEwen BS, Stellar E. Stress and the individual. Mechanisms leading to disease. Arch Intern Med (1993) 153:2093-101. doi:10. 1001/archinte.153.18.2093

34. Koob GF. A role for brain stress systems in addiction.
Neuron (2008) 59:11-34. doi:10. 1016/j.neuron.2008.06.012

35. Holsboer F, von Bardeleben U, Wiedemann K, Muller OA, Stalla GK. Serial assessment of corticotropin-releasing hormone response after dexamethasone in depression. Implications for pathophysiology of DST nonsuppression. Biol Psychiatry (1987) 22:228-34. doi:10.1016/00063223(87)90237-X

36. Nemeroff CB, Widerlov E, Bissette G, Walleus $\mathrm{H}$, Karlsson I, Eklund K, et al. Elevated concentrations of CSF corticotropin-releasing factor-like immunoreactivity in depressed patients. Science (1984) 226:1342-4. doi:10.1126/ science.6334362

37. Vyas A, Mitra R, Shankaranarayana Rao BS, Chattarji S. Chronic stress induces contrasting patterns of dendritic remodeling in hippocampal and amygdaloid neurons. JNeurosci (2002) 22:6810-8.

38. Lakshminarasimhan $\mathrm{H}$, Chattarji S. Stress leads to contrasting effects on the levels of brain derived neurotrophic factor in the hippocampus and amygdala. PLoS ONE (2012) 7:e30481. doi: 10.1371/journal.pone.0030481

39. Arendt DH, Smith JP, Bastida CC, Prasad MS, Oliver KD, Eyster KM, et al. Contrasting hippocampal and amygdalar expression of genes related to neural plasticity during escape from social aggression. Physiol Behav (2012) 107:670-9. doi:10. 1016/j.physbeh.2012.03.005

40. Kolber BJ, Roberts MS, Howell MP, Wozniak DF, Sands MS, Muglia LJ. Central amygdala glucocorticoid receptor action promotes fear-associated $\mathrm{CRH}$ activation and conditioning. Proc Natl Acad Sci U S A (2008) 105:12004-9. doi:10.1073/pnas.0803216105

41. Schwabe L, Tegenthoff M, Hoffken O, Wolf OT. Simultaneous glucocorticoid and noradrenergic activity disrupts the neural basis of goal-directed action in the human brain. $J$ Neurosci (2012) 32:10146-55. doi:10.1523/JNEUROSCI.130412.2012

42. Sarabdjitsingh RA, Kofink D, Karst H, de Kloet ER, Joels M. Stress-induced enhancement of mouse amygdalar synaptic plasticity depends on glucocorticoid and $\beta$-adrenergic activity. PLoS ONE (2012) 7:e42143. doi:10. 1371/journal.pone.0042143

43. Gourley SL, Swanson AM, Koleske AJ. Corticosteroidinduced neural remodeling predicts behavioral vulnerability and resilience. $J$ Neurosci (2013) 33:3107-12. doi:10.1523/JNEUROSCI.213812.2013

44. Lehmann ML, Brachman RA, Martinowich K, Schloesser RJ, Herkenham M. Glucocorticoids orchestrate divergent effects on mood through adult neurogenesis. JNeurosci (2013) 33:2961-72. doi:10.1523/JNEUROSCI.387812.2013

45. Meaney MJ, Diorio J, Francis D, Widdowson J, LaPlante P, Caldji $\mathrm{C}$, et al. Early environmental regulation of forebrain glucocorticoid receptor gene expression: implications for adrenocortical responses to stress. Dev Neurosci (1996) 18:49-72. doi:10.1159/000111395

46. Chen DY, Bambah-Mukku D, Pollonini G, Alberini CM. Glucocorticoid receptors recruit the CaMKIIalpha-BDNFCREB pathways to mediate memory consolidation. Nat Neurosci (2012) 15:1707-14. doi:10.1038/nn.3266

47. Gourley SL, Swanson AM, Jacobs AM, Howell JL, Mo M, Dileone RJ, et al. Action control is mediated by prefrontal BDNF and glucocorticoid receptor binding. Proc Natl Acad Sci U S A (2012) 109:20714-9. doi:10.1073/pnas.1208342109

48. Schwabe L, Oitzl MS, Philippsen C, Richter S, Bohringer A, Wippich W, et al. Stress modulates the use of spatial versus stimulus-response learning strategies in humans. Learn Mem (2007) 14:109-16. doi:10.1101/lm.435807

49. Schwabe L, Schachinger $\mathrm{H}$, de Kloet ER, Oitzl MS. Stress impairs spatial but not early stimulus-response learning. Behav Brain Res (2010) 213:50-5. doi:10.1016/j.bbr

50. ter Horst JP, van der Mark MH, Arp M, Berger S, de Kloet ER, Oitzl MS. Stress or no stress: mineralocorticoid receptors in the forebrain regulate behavioral adaptation. Neurobiol Learn Mem (2012) 98:33-40. doi:10.1016/j.nlm

51. Yuen EY, Liu W, Karatsoreos IN, Ren Y, Feng J, McEwen 
BS, et al. Mechanisms for acute stress-induced enhancement of glutamatergic transmission and working memory. Mol Psychiatry (2011) 16:15670. doi:10.1038/mp.2010.50

52. Lai M, Horsburgh K, Bae SE, Carter RN, Stenvers DJ, Fowler JH, et al. Forebrain mineralocorticoid receptor overexpression enhances memory, reduces anxiety and attenuates neuronal loss in cerebral ischaemia. Eur J Neurosci (2007) 25:1832-42. doi:10.1111/j.14609568.2007.05427.x

53. Richardson HN, Lee SY, O'Dell LE, Koob GF, Rivier CL. Alcohol self-administration acutely stimulates the hypothalamicpituitary-adrenal axis, but alcohol dependence leads to a dampened neuroendocrine state. Eur J Neurosci (2008) 28:1641-53. doi:10.1111/j.14609568.2008.06455.x

54. Wei Q, Fentress HM, Hoversten MT, Zhang L, Hebda-Bauer EK, Watson SJ, et al. Early-life forebrain glucocorticoid receptor overexpression increases anxiety behavior and cocaine sensitization. Biol Psychiatry (2012) 71:224-31. doi:10.1016/ j.biopsych.2011.07.009

55. de Jong IE, de Kloet ER. Glucocorticoids and vulnerability to psychostimulant drugs: toward substrate and mechanism. Ann N Y Acad Sci (2004) 1018:192-8. doi:10.1196/ annals.1296.022

56. Marinelli M, Piazza PV. Interaction between glucocorticoid hormones, stress and psychostimulant drugs. Eur J Neurosci (2002) 16:387-94. doi:10.1046/j.14609568.2002.02089.x

57. Roberts AJ, Lessov CN, Phillips TJ. Critical role for glucocorticoid receptors in stress- and ethanol-induced locomotor sensitization. J Pharmacol Exp Ther (1995) 275:790-7.

58. Rouge-Pont F, Marinelli M, Le Moal M, Simon H, Piazza PV. Stress-induced sensitization and glucocorticoids. II. Sensitization of the increase in extracellular dopamine induced by cocaine depends on stress-induced corticosterone secretion. J Neurosci (1995) 15:7189-95.

59. Saal D, Dong Y, Bonci A, Malenka RC. Drugs of abuse and stress trigger a common synaptic adaptation in dopamine neurons. Neuron (2003)
37:577-82. doi:10.1016/S08966273(03)00021-7

60. Tye SJ, Miller AD, Blaha CD. Differential corticosteroid receptor regulation of mesoaccumbens dopamine efflux during the peak and nadir of the circadian rhythm: a molecular equilibrium in the midbrain? Synapse (2009) 63:98290. doi:10.1002/syn.20682

61. Ambroggi F, Turiault M, Milet A, Deroche-Gamonet V, Parnaudeau S, Balado $\mathrm{E}$, et al. Stress and addiction: glucocorticoid receptor in dopaminoceptive neurons facilitates cocaine seeking. Nat Neurosci (2009) 12:247-9. doi:10.1038/nn.2282

62. Costin BN, Wolen AR, Fitting S, Shelton KL, Miles MF. Role of adrenal glucocorticoid signaling in prefrontal cortex gene expression and acute behavioral responses to ethanol. Alcohol Clin Exp Res (2013) 37:57-66. doi:10.1111/j.15300277.2012.01841.x

63. Cippitelli A, Damadzic R, Hamelink C, Brunnquell M, Thorsell A, Heilig M, et al. Binge-like ethanol consumption increases corticosterone levels and neurodegneration whereas occupancy of type II glucocorticoid receptors with mifepristone is neuroprotective. Addict Biol (2012). doi:10.1111/j.13691600.2012.00451.x

64. Prendergast MA, Mulholland PJ. Glucocorticoid and polyamine interactions in the plasticity of glutamatergic synapses that contribute to ethanol-associated dependence and neuronal injury. Addict Biol (2012) 17:209-23. doi:10.1111/j.13691600.2011.00375.x

65. Little HJ, Croft AP, O'Callaghan MJ, Brooks SP, Wang G, Shaw SG. Selective increases in regional brain glucocorticoid: a novel effect of chronic alcohol. Neuroscience (2008) 156:1017-27. doi:10.1016/j.neuroscience. 2008.08.029

66. Vendruscolo LF, Barbier E, Schlosburg JE, Misra KK, Whitfield TW Jr., Logrip ML, et al. Corticosteroid-dependent plasticity mediates compulsive alcohol drinking in rats. $J$ Neurosci (2012) 32:7563-71. doi:10.1523/JNEUROSCI.006912.2012

67. Rose AK, Shaw SG, Prendergast MA, Little HJ. The importance of glucocorticoids in alcohol dependence and neurotoxicity. Alcohol Clin Exp Res (2010) 34:2011-8. doi:10.1111/j.15300277.2010.01298.x

68. Yin $\mathrm{HH}$, Mulcare SP, Hilario MR, Clouse E, Holloway T, Davis MI, et al. Dynamic reorganization of striatal circuits during the acquisition and consolidation of a skill. Nat Neurosci (2009) 12:333-41. doi:10.1038/nn.2261

69. de Lecea L, Kilduff TS, Peyron C, Gao X, Foye PE, Danielson $\mathrm{PE}$, et al. The hypocretins: hypothalamus-specific peptides with neuroexcitatory activity. Proc Natl Acad Sci U S A (1998) 95:322-7. doi:10.1073/pnas.95.1.322

70. Sakurai T, Amemiya A, Ishii M, Matsuzaki I, Chemelli RM, Tanaka $\mathrm{H}$, et al. Orexins and orexin receptors: a family of hypothalamic neuropeptides and $G$ protein-coupled receptors that regulate feeding behavior. Cell (1998) 92:573-85. doi:10.1016/S00928674(02)09256-5

71. Anaclet C, Parmentier R, Ouk K, Guidon G, Buda C, Sastre JP, et al. Orexin/hypocretin and histamine: distinct roles in the control of wakefulness demonstrated using knock-out mouse models. J Neurosci (2009) 29:14423-38. doi:10.1523/JNEUROSCI.260409.2009

72. Chemelli RM, Willie JT, Sinton CM, Elmquist JK, Scammell $T$, Lee $C$, et al. Narcolepsy in orexin knockout mice: molecular genetics of sleep regulation. Cell (1999) 98:437-51. doi:10.1016/S00928674(00)81973-X

73. Haynes AC, Jackson B, Chapman H, Tadayyon M, Johns A, Porter RA, et al. A selective orexin-1 receptor antagonist reduces food consumption in male and female rats. Regul Pept (2000) 96:45-51. doi:10.1016/S01670115(00)00199-3

74. Yamada H, Okumura T, Motomura W, Kobayashi Y, Kohgo Y. Inhibition of food intake by central injection of antiorexin antibody in fasted rats. Biochem Biophys Res Commun (2000) 267:527-31. doi:10.1006/bbrc.1999.1998

75. Elias CF, Saper CB, Maratos-Flier E, Tritos NA, Lee C, Kelly J, et al. Chemically defined projections linking the mediobasal hypothalamus and the lateral hypothalamic area. J Comp
Neurol (1998) 402:442-59. doi:10.1002/(SICI) 1096-9861 (19981228)402:4<442::AIDCNE2 $>3.3 . \mathrm{CO} ; 2-\mathrm{I}$

76. Peyron C, Tighe DK, van den Pol AN, de Lecea L, Heller HC, Sutcliffe JG, et al. Neurons containing hypocretin (orexin) project to multiple neuronal systems. $J$ Neurosci (1998) 18:9996-10015.

77. Harris GC, Aston-Jones G. Arousal and reward: a dichotomy in orexin function. Trends Neurosci (2006) 29:571-7. doi:10.1016/j.tins.2006.08.002

78. Ida T, Nakahara K, Murakami T, Hanada R, Nakazato M, Murakami N. Possible involvement of orexin in the stress reaction in rats. Biochem Biophys Res Commun (2000) 270:318-23. doi:10.1006/bbrc.2000.2412

79. Kagerer SM, Johren O. Interactions of orexins/hypocretins with adrenocortical functions. Acta Physiol (Oxf) (2010) 198:361-71. doi:10.1111/j.17481716.2009.02034.x

80. Al-Barazanji KA, Wilson S, Baker J, Jessop DS, Harbuz MS. Central orexin-A activates hypothalamic-pituitary-adrenal axis and stimulates hypothalamic corticotropin releasing factor and arginine vasopressin neurones in conscious rats. J Neuroendocrinol (2001) 13:421-4. doi:10.1046/j.13652826.2001.00655.x

81. Jaszberenyi M, Bujdoso E, Pataki I, Telegdy G. Effects of orexins on the hypothalamicpituitary-adrenal system. J Neuroendocrinol (2000) 12:1174-8. doi:10.1046/j.13652826.2000.00572.x

82. Kuru M, Ueta $Y$, Serino $R$, Nakazato M, Yamamoto $Y$, Shibuya I, et al. Centrally administered orexin/hypocretin activates HPA axis in rats. Neuroreport (2000) 11:1977-80. doi:10.1097/00001756-2000062 60-00034

83. Kuwaki T, Zhang W. Orexin neurons and emotional stress. Vitam Horm (2012) 89:135-58. doi:10.1016/B978-0-12-3946232.00008-1

84. Di Chiara G, Imperato A. Ethanol preferentially stimulates dopamine release in the nucleus accumbens of freely moving rats. Eur J Pharmacol (1985) 115:131-2. doi:10.1016/00142999(85)90598-9

85. Koob GF, Bloom FE. Cellular and molecular mechanisms 
of drug dependence. Science (1988) 242:715-23. doi:10. 1126/science. 2903550

86. Wise RA, Rompre PP. Brain dopamine and reward. Annu Rev Psychol (1989) 40:191-225. doi:10.1146/annurev.ps.40.0201 89.001203

87. Borgland SL, Taha SA, Sarti F, Fields HL, Bonci A. Orexin A in the VTA is critical for the induction of synaptic plasticity and behavioral sensitization to cocaine. Neuron (2006) 49:589-601. doi:10.1016/ j.neuron.2006.01.016

88. DiLeone RJ, Georgescu D, Nestler EJ. Lateral hypothalamic neuropeptides in reward and drug addiction. Life Sci (2003) 73:759-68. doi:10.1016/S00243205(03)00408-9

89. Harris GC, Wimmer $M$, Aston-Jones G. A role for lateral hypothalamic orexin neurons in reward seeking. Nature (2005) 437:556-9. doi:10.1038/nature04071

90. Paneda C, Winsky-Sommerer R, Boutrel B, de Lecea L. The corticotropin-releasing factor-hypocretin connection: implications in stress response and addiction. Drug News Perspect (2005) 18:250-5. doi:10. 1358/dnp.2005.18.4.908659

91. Pasumarthi RK, Reznikov LR, Fadel J. Activation of orexin neurons by acute nicotine. Eur I Pharmacol (2006) 535:172-6. doi:10.1016/j.ejphar.2006.02.021

92. Dayas CV, McGranahan TM, Martin-Fardon R, Weiss F. Stimuli linked to ethanol availability activate hypothalamic CART and orexin neurons in a reinstatement model of relapse. Biol Psychiatry (2008) 63:152-7. doi:10. 1016/j.biopsych.2007.02.002

93. Jupp B, Krivdic B, Krstew E, Lawrence AJ. The orexin receptor antagonist SB-334867 dissociates the motivational properties of alcohol and sucrose in rats. Brain Res (2011) 1391:54-9. doi:10. 1016/j.brainres.2011.03.045

94. Lawrence AJ, Cowen MS, Yang HJ, Chen F, Oldfield B. The orexin system regulates alcohol-seeking in rats. $\mathrm{Br} J$ Pharmacol (2006) 148:752-9. doi:10.1038/sj.bjp.0706789

95. Moorman DE, Aston-Jones G. Orexin-1 receptor antagonism decreases ethanol consumption and preference selectively in high-ethanol - preferring Sprague - Dawley rats. Alcohol
(2009) 43:379-86. doi:10. 1016/j.alcohol.2009.07.002

96. Richards JK, Simms JA, Steensland $\mathrm{P}$, Taha SA, Borgland SL, Bonci $\mathrm{A}$, et al. Inhibition of orexin-1/hypocretin-1 receptors inhibits yohimbineinduced reinstatement of ethanol and sucrose seeking in LongEvans rats. Psychopharmacology (Berl) (2008) 199:109-17. doi:10.1007/s00213-008-1136-5

97. Srinivasan S, Simms JA, Nielsen CK, Lieske SP, Bito-Onon JJ, Yi H, et al. The dual orexin/hypocretin receptor antagonist, almorexant, in the ventral tegmental area attenuates ethanol selfadministration. PLoS ONE (2012) 7:e44726. doi:10.1371/ journal.pone.0044726

98. Kim AK, Brown RM, Lawrence AJ. The role of orexins/hypocretins in alcohol use and abuse: an appetitivereward relationship. Front Behav Neurosci (2012) 6:78. doi:10.3389/fnbeh.2012.00078

99. Shoblock JR, Welty N, Aluisio L, Fraser I, Motley ST, Morton $\mathrm{K}$, et al. Selective blockade of the orexin-2 receptor attenuates ethanol self-administration, place preference, and reinstatement. Psychopharmacology (Berl) (2011) 215:191-203. doi:10.1007/s00213-010-2127-x

100. Boutrel B, Kenny PJ, Specio SE, Martin-Fardon R, Markou A, Koob GF, et al. Role for hypocretin in mediating stress-induced reinstatement of cocaine-seeking behavior. Proc Natl Acad Sci U S A (2005) 102:19168-73. doi:10.1073/pnas.0507480102

101. Wang B, You ZB, Wise RA. Reinstatement of cocaine seeking by hypocretin (orexin) in the ventral tegmental area: independence from the local corticotropin-releasing factor network. Biol Psychiatry (2009) 65:857-62. doi:10. 1016/j.biopsych.2009.01.018

102. Jupp B, Krstew E, Dezsi G, Lawrence AJ. Discrete cueconditioned alcohol-seeking after protracted abstinence: pattern of neural activation and involvement of orexin(1) receptors. Br J Pharmacol (2011) 162:880-9. doi:10.1111/j.14765381.2010.01088.x

103. Moller C, Wiklund L, Sommer W, Thorsell A, Heilig M. Decreased experimental anxiety and voluntary ethanol consumption in rats following central but not basolateral amygdala lesions. Brain Res (1997) 760:94-101. doi:10.1016/S00068993(97)00308-9

104. McFarland K, Davidge SB, Lapish CC, Kalivas PW. Limbic and motor circuitry underlying footshock-induced reinstatement of cocaineseeking behavior. $J \mathrm{Neu}$ rosci (2004) 24:1551-60. doi:10.1523/JNEUROSCI.417703.2004

105. Schmidt FM, Arendt E, Steinmetzer A, Bruegel M, Kratzsch J, Strauss M, et al. CSF-hypocretin1 levels in patients with major depressive disorder compared to healthy controls. Psychiatry Res (2011) 190:240-3. doi: 10.1016/j.psychres.2011.06.004

106. Schmitt O, Usunoff KG, Lazarov NE, Itzev DE, Eipert P, Rolfs $\mathrm{A}$, et al. Orexinergic innervation of the extended amygdala and basal ganglia in the rat. Brain Struct Funct (2012) 217:233-56. doi:10.1007/s00429-011-0343-8

107. Lungwitz EA, Molosh A, Johnson PL, Harvey BP, Dirks RC, Dietrich A, et al. OrexinA induces anxiety-like behavior through interactions with glutamatergic receptors in the bed nucleus of the stria terminalis of rats. Physiol Behav (2012) 107:726-32. doi:10.1016/ j.physbeh.2012.05.019

108. Conrad KL, Davis AR, Silberman Y, Sheffler DJ, Shields AD, Saleh $\mathrm{SA}$, et al. Yohimbine depresses excitatory transmission in BNST and impairs extinction of cocaine place preference through orexin-dependent, norepinephrine-independent processes. Neuropsychopharmacology (2012) 37:2253-66. doi:10.1038/npp.2012.76

109. Winrow CJ, Gotter AL, Cox CD, Doran SM, Tannenbaum PL, Breslin MJ, et al. Promotion of sleep by suvorexant-a novel dual orexin receptor antagonist. $J$ Neurogenet (2011) 25:52-61. doi: 10.3109/01677063.2011.566953

110. Garrido P, De Blas M, Ronzoni G, Cordero I, Anton M, Gine $E$, et al. Differential effects of environmental enrichment and isolation housing on the hormonal and neurochemical responses to stress in the prefrontal cortex of the adult rat: relationship to working and emotional memories. $J$ Neural Transm (2013) 120:829-43. doi:10.1007/s00702-012-0935-3
111. Herman JP, Ostrander MM, Mueller NK, Figueiredo $\mathrm{H}$. Limbic system mechanisms of stress regulation: hypothalamopituitary-adrenocortical axis. Prog Neuropsychopharmacol Biol Psychiatry (2005) 29:1201-13. doi:10.1016/j.pnpbp.2005.08.006

112. Sullivan RM, Gratton A. Prefrontal cortical regulation of hypothalamic-pituitary-adrenal function in the rat and implications for psychopathology: side matters. Psychoneuroendocrinology (2002) 27:99-114. doi:10.1016/S03064530(01)00038-5

113. Weinberg MS, Johnson DC, Bhatt AP, Spencer RL. Medial prefrontal cortex activity can disrupt the expression of stress response habituation. $\mathrm{Neu}$ roscience (2010) 168:744-56. doi:10.1016/j.neuroscience.2010. 04.006

114. Gold PE. Acetylcholine modulation of neural systems involved in learning and memory. Neurobiol Learn Mem (2003) 80:194-210. doi:10.1016/j.nlm.2003.07.003

115. Levin HS, Rodnitzky RL. Behavioral effects of organophosphate in man. Clin Toxicol (1976) 9:391-403. doi:10.3109/15563657608988138

116. Kim JJ, Diamond DM. The stressed hippocampus, synaptic plasticity and lost memories. Nat Rev Neurosci (2002) 3:453-62.

117. McEwen BS. Effects of adverse experiences for brain structure and function. Biol Psychiatry (2000) 48:721-31. doi:10.1016/S00063223(00)00964-1

118. McEwen BS, Weiss JM, Schwartz LS. Selective retention of corticosterone by limbic structures in rat brain. Nature (1968) 220:911-2. doi:10.1038/220911a0

119. Del Arco A, Mora F. Neurotransmitters and prefrontal cortex-limbic system interactions: implications for plasticity and psychiatric disorders. $J$ Neural Transm (2009) 116:941-52. doi:10.1007/s00702-009-0243-8

120. Vizi ES, Kiss JP. Neurochemistry and pharmacology of the major hippocampal transmitter systems: synaptic and nonsynaptic interactions. Hippocampus (1998) 8:566-607. doi:10.1002/(SICI) 1098-1063 (1998) 8:6<566::AID-HIPO2> 3.0.CO;2-W 
121. Imperato A, Puglisi-Allegra S, Casolini P, Angelucci L. Changes in brain dopamine and acetylcholine release during and following stress are independent of the pituitary-adrenocortical axis. Brain Res (1991) 538:111-7. doi:10.1016/00068993(91)90384-8

122. Ross SA, Wong JY, Clifford JJ, Kinsella A, Massalas JS, Horne $\mathrm{MK}$, et al. Phenotypic characterization of an alpha 4 neuronal nicotinic acetylcholine receptor subunit knock-out mouse. J Neurosci (2000) 20:6431-41.

123. Booker TK, Butt CM, Wehner JM, Heinemann SF, Collins AC. Decreased anxiety-like behavior in beta3 nicotinic receptor subunit knockout mice. Pharmacol Biochem Behav (2007) 87:146-57. doi:10.1016/j.pbb.2007.04.011

124. Salas R, Pieri F, Fung B, Dani JA, De Biasi M. Altered anxietyrelated responses in mutant mice lacking the beta4 subunit of the nicotinic receptor. J Neurosci (2003) 23:6255-63.

125. Salas R, Orr-Urtreger A, Broide RS, Beaudet A, Paylor R, De Biasi M. The nicotinic acetylcholine receptor subunit alpha 5 mediates short-term effects of nicotine in vivo. Mol Pharmacol (2003) 63:1059-66. doi:10.1124/mol.63.5.1059

126. Salas R, Pieri F, De Biasi M. Decreased signs of nicotine withdrawal in mice null for the beta4 nicotinic acetylcholine receptor subunit. J Neurosci (2004) 24:10035-9. doi:10.1523/JNEUROSCI.193904.2004

127. Brioni JD, O’Neill AB, Kim DJ, Decker MW. Nicotinic receptor agonists exhibit anxiolytic-like effects on the elevated plus-maze test. Eur J Pharmacol (1993) 238:1-8. doi:10.1016/00142999(93)90498-7

128. Cao W, Burkholder T, Wilkins L, Collins AC. A genetic comparison of behavioral actions of ethanol and nicotine in the mirrored chamber. Pharmacol Biochem Behav (1993) 45:803-9. doi:10.1016/00913057(93)90124-C

129. Costall B, Kelly ME, Naylor RJ, Onaivi ES. The actions of nicotine and cocaine in a mouse model of anxiety. Pharmacol Biochem Behav (1989) 33:197-203. doi:10.1016/00913057(89)90450-4
130. File SE, Cheeta S, Kenny PJ. Neurobiological mechanisms by which nicotine mediates different types of anxiety. Eur J Pharmacol (2000) 393:231-6. doi:10.1016/S00142999(99)00889-4

131. Alzoubi KH, Srivareerat M, Tran TT, Alkadhi KA. Role of alpha7and alpha4beta2-nAChRs in the neuroprotective effect of nicotine in stress-induced impairment of hippocampus-dependent memory. Int J Neuropsychopharmacol (2013) 16:1105-13. doi:10.1017/S1461145712001046

132. Akana SF, Chu A, Soriano L, Dallman MF. Corticosterone exerts site-specific and statedependent effects in prefrontal cortex and amygdala on regulation of adrenocorticotropic hormone, insulin and fat depots. J Neuroendocrinol (2001) 13:625-37. doi:10.1046/j.13652826.2001.00676.x

133. Feldman S, Conforti N, Saphier D. The preoptic area and bed nucleus of the stria terminalis are involved in the effects of the amygdala on adrenocortical secretion. Neuroscience (1990) 37:775-9. doi:10.1016/03064522(90)90107-F

134. Herman JP, Schafer MK, Young EA, Thompson R, Douglass J, Akil $\mathrm{H}$, et al. Evidence for hippocampal regulation of neuroendocrine neurons of the hypothalamo-pituitaryadrenocortical axis. J Neurosci (1989) 9:3072-82.

135. Jacobson L, Sapolsky R. The role of the hippocampus in feedback regulation of the hypothalamicpituitary-adrenocortical axis. Endocr Rev (1991) 12:118-34. doi:10.1210/edrv-12-2-118

136. Sapolsky RM, Krey LC, McEwen BS. Glucocorticoid-sensitive hippocampal neurons are involved in terminating the adrenocortical stress response. Proc Natl Acad Sci U S A (1984) 81:6174-7. doi:10.1073/pnas.81.19.6174

137. Matta SG, Beyer HS, McAllen KM, Sharp BM. Nicotine elevates rat plasma ACTH by a central mechanism. J Pharmacol Exp Ther (1987) 243:217-26.

138. Matta SG, McAllen KM, Sharp BM. Role of the fourth cerebroventricle in mediating rat plasma ACTH responses to intravenous nicotine. Pharmacol Exp Ther (1990) 252:623-30.
139. Sawchenko PE, Bohn MC. Glucocorticoid receptorimmunoreactivity in $\mathrm{C} 1, \mathrm{C} 2$, and $\mathrm{C} 3$ adrenergic neurons that project to the hypothalamus or to the spinal cord in the rat. $J$ Comp Neurol (1989) 285:107-16. doi:10.1002/cne.902850109

140. Swanson LW, Sawchenko PE Rivier J, Vale WW. Organization of ovine corticotropinreleasing factor immunoreactive cells and fibers in the rat brain: an immunohistochemical study. Neuroendocrinology (1983) 36:165-86. doi:10.1159/ 000123454

141. Fu Y, Matta SG, Valentine JD, Sharp BM. Adrenocorticotropin response and nicotine-induced norepinephrine secretion in the rat paraventricular nucleus are mediated through brainstem receptors. Endocrinology (1997) 138:1935-43. doi:10.1210/en.138.5.1935

142. Zhao R, Chen H, Sharp BM. Nicotine-induced norepinephrine release in hypothalamic paraventricular nucleus and amygdala is mediated by $\mathrm{N}$ methyl-D-aspartate receptors and nitric oxide in the nucleus tractus solitarius. J Pharmacol Exp Ther (2007) 320:837-44. doi:10.1124/jpet.106.112474

143. Sawchenko PE, Swanson LW. The organization of noradrenergic pathways from the brainstem to the paraventricular and supraoptic nuclei in the rat. Brain Res (1982) 257:275-325

144. Swanson LW, Sawchenko PE, Berod A, Hartman BK, Helle KB, Vanorden DE. An immunohistochemical study of the organization of catecholaminergic cells and terminal fields in the paraventricular and supraoptic nuclei of the hypothalamus. $J$ Comp Neurol (1981) 196:271-85. doi:10.1002/cne.901960207

145. Kalappa BI, Feng L, Kem WR, Gusev AG, Uteshev VV. Mechanisms of facilitation of synaptic glutamate release by nicotinic agonists in the nucleus of the solitary tract. Am J Physiol Cell Physiol (2011) 301:C347-61. doi:10.1152/ajpcell.00473.2010

146. Smith DV, Uteshev VV. Heterogeneity of nicotinic acetylcholine receptor expression in the caudal nucleus of the solitary tract. Neuropharmacology (2008) 54:445-53. doi:10.1016/j.neuropharm.2007. 10.018
147. Bullock AE, Clark AL, Grady SR, Robinson SF, Slobe BS, Marks MJ, et al. Neurosteroids modulate nicotinic receptor function in mouse striatal and thalamic synaptosomes. J Neurochem (1997) 68:2412-23. doi:10.1046/j.14714159.1997.68062412.x

148. Ke L, Lukas RJ. Effects of steroid exposure on ligand binding and functional activities of diverse nicotinic acetylcholine receptor subtypes. J Neurochem (1996) 67:1100-12. doi:10.1046/j.14714159.1996.67031100.x

149. Shi LJ, He HY, Liu LA, Wang CA. Rapid nongenomic effect of corticosterone on neuronal nicotinic acetylcholine receptor in PC12 cells. Arch Biochem Biophys (2001) 394:145-50. doi:10.1006/abbi.2001.2519

150. Takita M, Muramatsu I. Alteration of brain nicotinic receptors induced by immobilization stress and nicotine in rats. Brain Res (1995) 681:190-2. doi:10.1016/00068993(95)00265-R

151. Almeida LE, Pereira EF, Alkondon M, Fawcett WP, Randall WR, Albuquerque EX. The opioid antagonist naltrexone inhibits activity and alters expression of alpha7 and alpha4beta2 nicotinic receptors in hippocampal neurons: implications for smoking cessation programs. Neuropharmacology (2000) 39:2740-55. doi:10.1016/S0028 3908(00)00157-X

152. Leonard S, Gault J, Hopkins J, Logel J, Vianzon R, Short M, et al. Association of promoter variants in the alpha7 nicotinic acetylcholine receptor subunit gene with an inhibitory deficit found in schizophrenia. Arch Gen Psychiatry (2002) 59:1085-96. doi:10.1001/archpsyc.59.12.1085

153. Berse B, Blusztajn JK. Modulation of cholinergic locus expression by glucocorticoids and retinoic acid is cell-type specific. FEBS Lett (1997) 410:175-9. doi:10.1016/S00145793(97)00568-1

154. Battaglia M, Ogliari A. Anxiety and panic: from human studies to animal research and back. Neurosci Biobehav Rev (2005) 29:169-79. doi:10. 1016/j.neubiorev.2004.06.013

155. Meshorer E, Soreq H. Virtues and woes of AChE alternative splicing in stress-related neuropathologies. Trends 
Neurosci (2006) 29:216-24. doi:10.1016/j.tins.2006.02.005

156. Meerson A, Cacheaux L, Goosens KA, Sapolsky RM, Soreq H, Kaufer D. Changes in brain MicroRNAs contribute to cholinergic stress reactions. $J$ Mol Neurosci (2010) 40:47-55. doi:10.1007/s12031-009-9252-1

157. Shaltiel G, Hanan M, Wolf Y, Barbash S, Kovalev E, Shoham S, et al. Hippocampal microRNA132 mediates stress-inducible cognitive deficits through its acetylcholinesterase target. Brain Struct Funct (2013) 218:59-72. doi:10.1007/s00429-011-0376-Z

158. Zhao T, Huang GB, Muna SS, Bagalkot TR, Jin HM, Chae HJ, et al. Effects of chronic social defeat stress on behavior and choline acetyltransferase, 78-kDa glucose-regulated protein, and CCAAT/enhancerbinding protein (C/EBP) homologous protein in adult mice. Psychopharmacology (Berl) (2013) 228:217-30. doi:10.1007/s00213-013-3028-6

159. Sailaja BS, Cohen-Carmon D, Zimmerman G, Soreq $\mathrm{H}$, Meshorer E. Stress-induced epigenetic transcriptional memory of acetylcholinesterase by HDAC4. Proc Natl Acad Sci U S A (2012) 109:E3687-95. doi:10.1073/pnas.1209990110

160. Kaufer D, Friedman A, Seidman S, Soreq H. Acute stress facilitates long-lasting changes in cholinergic gene expression. Nature (1998) 393:373-7. doi:10.1038/30741

161. Pavlovsky L, Bitan Y, Shalev $\mathrm{H}$, Serlin Y, Friedman A. Stress-induced altered cholinergic-glutamatergic interactions in the mouse hippocampus. Brain Res (2012) 1472:99-106. doi:10. 1016/j.brainres.2012.05.057

162. Fahlke C, Hard E, Eriksson CJ, Engel JA, Hansen S. Consequence of long-term exposure to corticosterone or dexamethasone on ethanol consumption in the adrenalectomized rat, and the effect of type I and type II corticosteroid receptor antagonists. Psychopharmacology (Berl) (1995) 117:216-24. doi:10.1007/BF02245190
163. Uhart M, Wand GS. Stress, alcohol and drug interaction: an update of human research. Addict Biol (2009) 14:43-64. doi:10.1111/j.13691600.2008.00131.x

164. Sinha R. The role of stress in addiction relapse. Curr Psychiatry Rep (2007) 9:388-95. doi:10.1007/s11920-007-0050-6

165. Sinha R, Catapano D, O'Malley S. Stress-induced craving and stress response in cocaine dependent individuals. Psychopharmacology (Berl) (1999) 142:343-51. doi:10.1007/s002130050898

166. Simms JA, Haass-Koffler CL, Bito-Onon J, Li R, Bartlett SE. Mifepristone in the central nucleus of the amygdala reduces yohimbine stress-induced reinstatement of ethanol-seeking. Neuropsychopharmacology (2012) 37:906-18. doi:10.1038/ npp.2011.268

167. De Vries TJ, Schoffelmeer AN, Tjon GH, Nestby P, Mulder AH, Vanderschuren LJ. Mifepristone prevents the expression of long-term behavioural sensitization to amphetamine. Eur J Pharmacol (1996) 307:R3-4. doi:10.1016/00142999(96)00308-1

168. Deroche-Gamonet V, Sillaber I, Aouizerate B, Izawa R, Jaber M, Ghozland S, et al. The glucocorticoid receptor as a potential target to reduce cocaine abuse. $J$ Neurosci (2003) 23:4785-90.

169. Fiancette JF, Balado E, Piazza PV, Deroche-Gamonet V. Mifepristone and spironolactone differently alter cocaine intravenous self-administration and cocaine-induced locomotion in C57BL/6] mice. Addict Biol (2010) 15:81-7. doi:10.1111/j.13691600.2009.00178.x

170. Mesripour A, Haihashemi V, Rabbani M. Metyrapone and mifepristone reverse recognition memory loss induced by spontaneous morphine withdrawal in mice. Basic Clin Pharmacol Toxicol (2008) 102:377-81. doi:10.1111/j.17427843.2007.00183.x

171. Jacquot C, Croft AP, Prendergast MA, Mulholland $P$, Shaw SG, Little HJ. Effects of the glucocorticoid antagonist, mifepristone, on the consequences of withdrawal from long term alcohol consumption. Alcohol Clin Exp Res (2008) 32:2107-16. doi:10.1111/j.15300277.2008.00799.x

172. Koenig HN, Olive MF. The glucocorticoid receptor antagonist mifepristone reduces ethanol intake in rats under limited access conditions. Psychoneuroendocrinology (2004) 29:999-1003. doi:10. 1016/j.psyneuen.2003.09.004

173. Lowery EG, Spanos M, Navarro M, Lyons AM, Hodge CW, Thiele TE. CRF-1 antagonist and CRF-2 agonist decrease binge-like ethanol drinking in C57BL/6J mice independent of the HPA axis. Neuropsychopharmacology (2010) 35:1241-52. doi:10.1038/npp.2009.209

174. O'Callaghan MJ, Croft AP, Jacquot C, Little HJ. The hypothalamopituitaryadrenal axis and alcohol preference. Brain Res Bull (2005) 68:171-8. doi:10. 1016/j.brainresbull.2005.08.006

175. Yang $X$, Wang S, Rice $K C$ Munro CA, Wand GS. Restraint stress and ethanol consumption in two mouse strains. Alcohol Clin Exp Res (2008) 32:840-52. doi:10.1111/j.15300277.2008.00632.x

176. Sharrett-Field L, Butler TR, Berry JN, Reynolds AR, Prendergast MA. Mifepristone pretreatment reduces ethanol withdrawal severity in vivo. Alcohol Clin Exp Res (2013):doi:10.1111/acer.12093

177. Johanssen S, Allolio B. Mifepristone (RU 486) in Cushing's syndrome. Eur J Endocrinol (2007) 157:561-9. doi:10.1530/EJE-070458

178. DeBattista C, Belanoff J. The use of mifepristone in the treatment of neuropsychiatric disorders. Trends Endocrinol Metab (2006) 17:117-21. doi:10.1016/j.tem.2006.02.006

179. Gallagher P, Watson S, Elizabeth Dye C, Young AH, Nicol Ferrier I. Persistent effects of mifepristone (RU-486) on cortisol levels in bipolar disorder and schizophrenia. JPsychiatr Res
(2008) 42:1037-41. doi:10.1016/ j.jpsychires.2007.12.005

180. Gallagher P, Watson S, Smith MS, Ferrier IN, Young AH. Effects of adjunctive mifepristone (RU486) administration on neurocognitive function and symptoms in schizophrenia. Biol Psychiatry (2005) 57:155-61. doi: 10.1016/j.biopsych.2004.10.017

181. Gallagher P, Young AH. Mifepristone (RU-486) treatment for depression and psychosis: a review of the therapeutic implications. Neuropsychiatr Dis Treat (2006) 2:33-42.

182. Wulsin AC, Herman JP, Solomon MB. Mifepristone decreases depression-like behavior and modulates neuroendocrine and central hypothalamicpituitary-adrenocortical axis responsiveness to stress. Psychoneuroendocrinology (2010) 35:1100-12. doi:10.1016/ j.psyneuen.2010.01.011

183. Young AM. Antiglucocorticoid treatments for depression. Aust N Z J Psychiatry (2006) 40:402-5. doi:10.1080/j.14401614.2006.01813.x

Conflict of Interest Statement: The authors declare that the research was conducted in the absence of any commercial or financial relationships that could be construed as a potential conflict of interest.

Received: 13 April 2013; accepted: 28 June 2013; published online: 01 August 2013. Citation: Srinivasan S, Shariff $M$ and Bartlett SE (2013) The role of the glucocorticoids in developing resilience to stress and addiction. Front. Psychiatry 4:68. doi: 10.3389/fpsyt.2013.00068

This article was submitted to Frontier in Addictive Disorders and Behavioral Dyscontrol, a specialty of Frontiers in Psychiatry.

Copyright $\odot 2013$ Srinivasan, Shariff and Bartlett. This is an open-access article distributed under the terms of the Creative Commons Attribution License (CC $B Y)$. The use, distribution or reproduction in other forums is permitted, provided the original author(s) or licensor are credited and that the original publication in this journal is cited, in accordance with accepted academic practice. No use, distribution or reproduction is permitted which does not comply with these terms. 